\title{
Taxonomic Review of Fungivorous Tetratomidae (Coleoptera: Tetratomidae) in Korea with New Host Fungi
}

\author{
Boo Hee Jung* \\ Department of Life Science, Yeongnam University, Gyeongsangbuk-do, 712-749, Korea
}

\section{한국산 균식성 애버섯벌리붙이과 Coleoptera: Tetratomidae]의 분류학적 검토와 숙주버섯 \\ 정부희 ${ }^{*}$ \\ 영남대학교 생명과학과}

\begin{abstract}
A taxonomic review of the fungivorous tetratomid beetles in Korea, which comprises four species belonging to two genera of two subfamilies, is presented. Three species, Holostrophus (Paraholostrophus) orientalis Lewis, 1895 and two newly recorded species, Pisenus insignis (Reitter, 1889) and Holostrophus diversefasciatus Pic, 1921, are identified and described herein. A photograph of adults, diagnoses, illustrations of diagnostic characteristics, and ecological information regarding habitat, and host fungi are provided.
\end{abstract}

Key words: Pisenus insignis (Reitter), Holostrophus diversefasciatus Pic, Tetratomidae, Taxonomy, Host fungi.

초 록: 한국산 균식성 애버섯벌레붙이과에 대한 분류학적 검토를 수행하였다. 한국산 균식성 애버섯벌레붙이과에는 2아과와 2속에 속한 4 종이 포 함되어 있으나, 본 논문에서는 3종을 검토하였다. 그 가운데 2종 <Pisenus insignis (Reitter, 1889) and Holostrophus diversefasciatus Pic, 1921> 은 한국에서 처음으로 보고되는 종들이다. 성충의 사진, 진단 형질, 특징적인 형질, 서식지를 포함한 생태적 정보와 숙주버섯을 제공하였다.

검색어: 애버섯벌레붙이과, 털보애버섯벌레붙이, 두줄무늬애버섯벌레붙이, 미기록종, 숙주버섯

The beetle Tetratomidae Billberg is a relatively small family, which comprises 13 genera and about 155 species arranged into five subfamilies and it is distributed mainly in the Holarctic region except the Australian (Leschen, 1990; Nikitsky, 1998; Young and Pollock, 2002).

The tetratomids are commonly fungivorous. They mainly inhabit in the fruiting bodies of higher fungi (Crowson, 1964; Lawrence, 1982), Hymenomycete fungi, especially Polyporaceae and Tricholomataceae (Young and Pollock, 2002). Both larvae and adults typically feed and breed in the fruiting bodies of polypores and other lignicolous basidiomycetes fungi (Park et

*Comesponding author: starrylight12@hanmail.net Received March 24 2011; Revised May 23 2011; Accepted June 152011 al., 1931; Minch, 1952; Graves, 1960; Miyatake, 1960; Lawrence, 1982; Leschen, 1990).

This family may well be paraphyletic (Lawrence and Newton, 1995). Tetratomidae was first recognized as an independent family by Crowson (1955). Tetratomids was previously treated as several tribes of the families Melandryidae and Mycetophagidae (Crowson, 1955; Miyatake, 1960; Nikitsky, 1992, 1998; Lawrence and Newton, 1995; Young and Pollock, 2002). Recently several lineages of melandryids and mycetophagids were placed in tetratomid group, based upon character sets from both larvae and adults (Miyatake, 1960; Hayashi, 1975; Nikitsky, 1989, 1998).

The family can be separated from melandryids and mycetophagids by the front coxal cavities opened behind externally and 
internally, with small lateral extension exposing trochantin partially and tarsal formular 5-5-4 (Crowson, 1955; Miyatake, 1960; Nikitsky, 1998; Young and Pollock, 2002).

Although Pisenus chujoi Miyatake was first reported in Korean fauna by Kim and Kim (1996), there were no specimens which presented concrete evidence of the record. Since then Nikitsky(1998) first reported Holostrophus (Paraholostrophus) orientalis Lewis to Korea without any distributional information.

In this paper, four species including two new record Pisenus insignis (Reitter) and Holostrophus diversefasciatus Pic are reported to Korea. Author also first describes the relationship between Korean tetratomids and its host fungi, and provide ecological information regarding their habitats, based on specimens reared in the laboratory and field observations. Diagnoses, habitus photos of adults, fungal hosts, and illustrations of diagnostic characters are provided.

Materials for this study were collected from host fungi growing on dead or decaying trees and then reared in the laboratory. In this study, the following 5 stages of maturation of the fruiting body were recognized: 1) stage I means the first appearance of the young, growing fruiting body; 2) stage II means the old fruiting body between the maturation of the spores and dissemination of ripe spore; 3 ) stage III means the beginning of tissue breakdown in the conk; 4) stage IV means the rapidly decaying stage of the fruiting body; and 5) stage $\mathrm{V}$ means mounting stage (Graves, 1960; Klimaszewski and Peck, 1987). The specimens examined in this study were deposited in the JUNG's Insect Collection (Seoul, Korea). Abbreviations are as follows: GW, Gangwondo; GS, Gyeonggido-Seoul; and JB, Jeollabukdo.

\section{Species accounts}

Family Tetratomidae Billberg, 1820 애버섯벌레붙이과

\section{Key to the subfamilies of Korean Tetratomidae}

1. Apical 3 antennomeres broadened

Piseninae Miyatake

- Apical 3-7 antennomeres usually broadened

Eustrophinae Gistel
Piseninae Miyatake, 1960 털보애버섯벌레붙이아과

\section{Genus Pisenus Casey 털보애버섯벌레붙이속}

Pisenus Casey, 1900: 167.

Type species: Cryptophagus humeralis Kirby, 1837

Diagnosis. Eyes emarginate anteriad, usually strongly transverse; antennae with three apical antennomeres clubbed, covered with uneven hairs; hind wings with closed anal cell (Miyatake, 1960).

\section{Key to the species of Korean Pisenus}

1. Body elongate-oval and moderately convex; Antenna sufmoniliform, widening from 6th to 8th antennomeres (Miyatake, 1960)

P. chujoi

- Body cylindrical, strongly convex; Antenna sufmoniliform, widening from 4 th to 8 th antennomeres p. insignis

Pisenus insignis (Reitter) 털보애버섯벌레붙이 (신칭)

(Figs. 1, 4, 5, 6)

Pseudotryphyllus insign's Reitter, 1889: 245.

Pisenus insignis: Miyatake, 1960: 121.

Diagnosis. Body length 2.5-3.5 mm, 2.5-1.9 mm in width. Body elongate-oval, strongly convex, glossy; with short, fine and subdecumbent yellowish hairs; antennae, mouth-parts, elytra (except fascia) and legs reddish brown; head and pronotum black. Head with coarse, large and dense punctures; antenna submoniliform, widening from antennomere 8 to apex; 4th maxillary palpomere cylindrical. Pronotum convex; with sparse, strong and large punctures; slightly narrower than basal elytra; almost parallel-sided; anterior margin straight; lateral sides roundly narrowing anteriad and posteriad; basal margin slightly sinuous. Elytra not striate; convex, with sparse and strong punctures; elytral variate in color; typical form unicolor, reddish brown; variation form usually with triangular patch on and around scutellum, and broad black transverse band at 

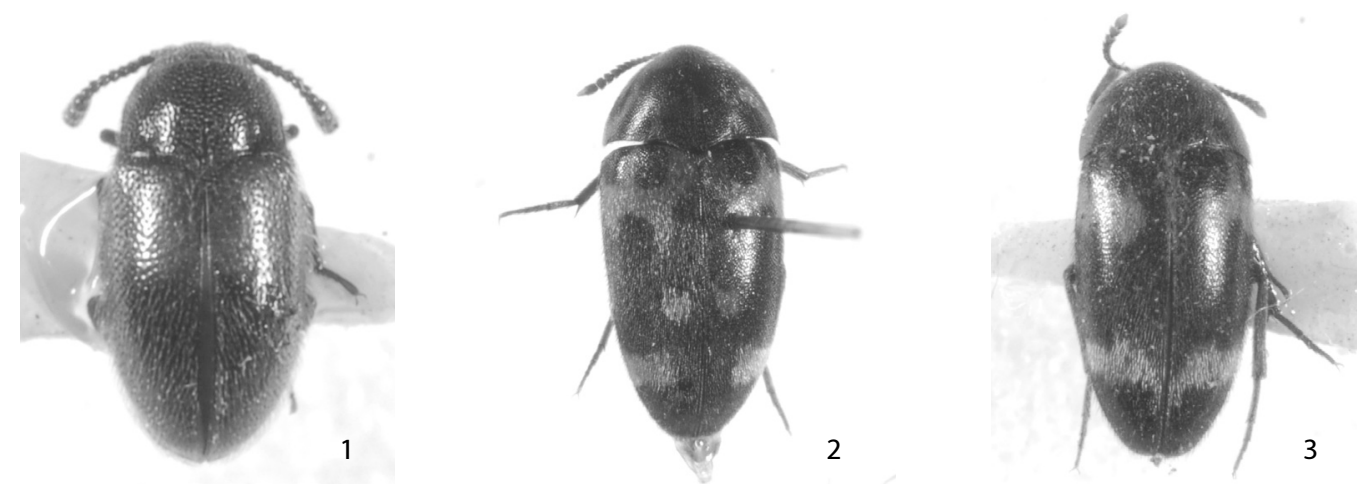

Figs. 1-3. Habitus of Tetratomidae. 1. Pisenus insignis, 2. Holostrophus (Paraholostrophus) orientalis, 3. Holostrophus diversefasciatus (female).

middle part and apical part; or sometimes scutellar patch extended posteriad and connected with median band.

Specimens examined. $<\mathbf{G W}>$ : 20exs. Temple Weoljeong-sa, Odae-san Jinbu-myeon, Pyeongchang-gun, 2 VI 2007, B.-H. Jung ex Heterobasidion insularis (Murr.) Ryv. (successional stage III); <GS>: 6exs. Yumyeong-san, Gail-ri, Seolak-myeon, Gapyeong-gun, 22 IV 2007, B.-H. Jung ex Heterobasidion insularis (Murr.) Ryv. (successional stage III); 2exs. Mt. Yumyeong-san, Gail-ri, Seolak-myeon, Gapyeong-gun, 22 IV 2007, B.-H. Jung ex Coriolus versicolor (L.: Fr.) Quél. (successional stage III); 2exs. Mt. Yumyeong-san, Gail-ri, Seolak-myeon, Gapyeong-gun, 22 IV 2009, B.-H. Jung ex Heterobasidion insularis (Murr.) Ryv. (successional stage III); $<\mathbf{J B}>$ : 1exs. Temple Geumsan-sa, Moak-san, Gemsan-ri, Gapyeong-myeon, Gimje-si, 15 IV 2007, B.-H. Jung ex Daedaleopsis tricolor (Bull.: Fr.) Bond. et Sing. (successional stage III).

Distribution. Korea (Central, South - new record), Japan (Honshu, Shikoku), Russia (Far East).

Host fungi. Heterobasidion insularis (Murr.) Ryv., Coriolus versicolor (L.: Fr.) Quél., Daedaleopsis tricolor (Bull.: Fr.) Bond. et Sing.

Biological notes. Pisenus insignis (Reitter) is the mycetobiont which is obligatory fungal inhabitants. This species inhabit in the fruiting bodies of Polyporace (e. g. Heterobasidion, Coriolus, Daedaleopsis), which are lignicolous and longevous. Especially it fed and collected in the successional stages III of host fungi, which the fruiting body begins to decay. Also host fungi of this species is thick enough to feed and breed in fruiting body, of which thickness were ranged from $1.0 \mathrm{~mm}$ to $8.0 \mathrm{~mm}$. This species is polyphagous, therefore more common in the most decayed fruiting bodies.

\section{Pisenus chujoi Miyatake}

Pisenus chujoi Miyatake, 1960: 129; Kim and Kim, 1996: 121; Nikitsky, 1998: 28; Kim, 2002: 230.

Remarks. Pisenus chujoi Miyatake was first reported in Korean fauna by Kim and Kim (1996), and also was cited on the list of Korean Coleoptera by Kim (2002). This species is not examined because there were no specimens in the deposited collection which referred literally. There were not presented any concrete evidence and information such as specimens in the data of Kim and Kim (1996). Thus, this species has been never checked up and collected yet in the field. Accordingly, it is not reported from Korea until now.

\section{Eustrophinae Gistel, 1856 무니애버섯벌레붙이아과}

\section{Genus Holostrophus Horn 무늬애버섯벌레붙이속}

Holostrophus Horn, 1888: 36.

Type species: Eustrophus bifasciatus Say, 1824.

Diagnosis. Eyes more strongly sinuate and more strongly approximate to each other, distance between eyes less than ocular transverse diameter. Prosternal process usually strongly 
surpassing posterior edge of procoxae. Elytra dark with red pattern (Nikitsky, 1998).

\section{Key to the species of Korean Holostrophus}

1. Elytra with two fascia bands at basal and apical parts H. diversefasciatus

- Elytra with four fascia bands at basal, middle, subapical and apical parts

H. orientalis

\section{Holostrophus orientalis Lewis 동양무늬애버섯벌레붙 이(신칭)}

(Figs. 2, 7, 10)

Holostrophus orientalis Lewis, 1895: 259.

Diagnosis. Body length 4.5-6.8 mm. Body elliptical, elongate-oval, convex, weakly glossy; with short, decumbent and golden hairs; head reddish brown; antennomeres 1-4, apical part of head and mouthparts yellowish brown; pronotum partially black; elytra black, with 4 yellowish brown fascia bands. Head downward; eyes emarginate; antennae widening from antennomere 6 to apex; apical antennomere long triangular; 4th maxillary palpomere triangular. Pronotum triangular, with fine, dense punctures; with distinct lateral carinae; all lateral margins slightly marginate, not visible dorsally; basal margin sinuous, with short longitudinal sulcus on subbasal part. Elytra not striate; black, with reddish brown fascia at basal part, divided into two round dusky spots on basal edge; one spot placed near humeral angle, other fascia bidentate placed near lateral sides; irregular reddish spot at middle part; simple fascia band extended at subapical and apical parts. All legs slender; all tibiae with two spurs at apex.

Specimens examined. <GS >: 1 ex. Saneum Hyuyangrim, Yanpyeong-gun, 13 X 2006, B.-H. Jung ex Oligophorous sp. (successional stage II); lex. Jungmi-san, Yanpyeong-gun, $3 \mathrm{X}$ 2006, B.-H. Jung ex Oligophours sp.(successional stage II); 2ex. Wongok-dong, Ansan-si, 12 V 2006, B.-H. Jung ex Coriolus versicolor (L.: Fr.) Quél.(successional stage II); 1ex. Mugap-san, Toechon-ri, Gwangju-gun, 27 V 2006, B.-H. Jung ex Bjerkandera adusta (Fr.) Karst. (successional stage III); lex. Gildong Ecological Park, Gil-dong, Gangdong-gu, Seoul-si, 22 VI 2006, B.-H. Jung ex Mycelina; 1 ex. Iseongsanseong, Hanam-si, 1 VII 2006, B.-H. Jung ex mycelia; 1ex. Mani-san, Hwado-myeon, Gangwha-gun, 8 VIII 2009, B.-H. Jung ex Laetiporus sulphureus (Fr.) Murr. (successional stage II); 1ex. Bijo-bong, Deokjeokmyeon, Deokjeok island, Ongjin-gun, Incheon-si, 24 X 2009, B.-H. Jung and A-Y. Kim ex rotten wood.

Distribution. Korea, Japan, China, Taiwan.

Host fungi. Oligophours sp., Coriolus versicolor (L.: Fr.) Quél., Bjerkandera adusta (Fr.) Karst., Laetiporus sulphureus (Fr.) Murr., and Mycelia,

Biological notes. Holostrophus (Paraholostrophus) orientalis is the mycetobiont which is obligatory fungal inhabitants. Thus, this species selects the host fungi according to biological characteristics of the fungus, such as longevity of the fruiting body and rot type. This species inhabit in the fruiting bodies of Polyporace (e.g. Bjerkandera, Coriolus, Laetiporus), which are lignicolous and longevous. Especially it fed and collected in the
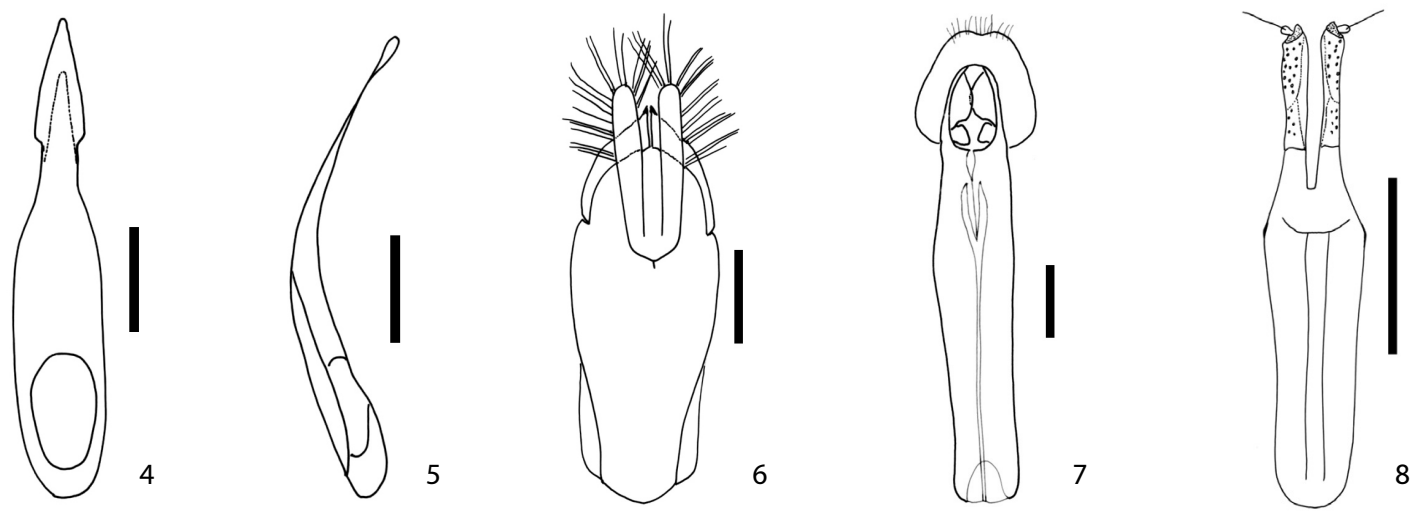

Figs. 4-8. Genitalia of Tetratomidae. (Each scale bar $=0.1 \mathrm{~mm}$ ). 4. Pisenus insignis (median lobe; dorsal); 5 . Pisenus insignis (median lobe; lateral); 6. Pisenus insignis (tegmen, dorsal view); 7. Holostrophus (Paraholostrophus) orientalis, 8. Holostrophus diversefasciatus (female). 

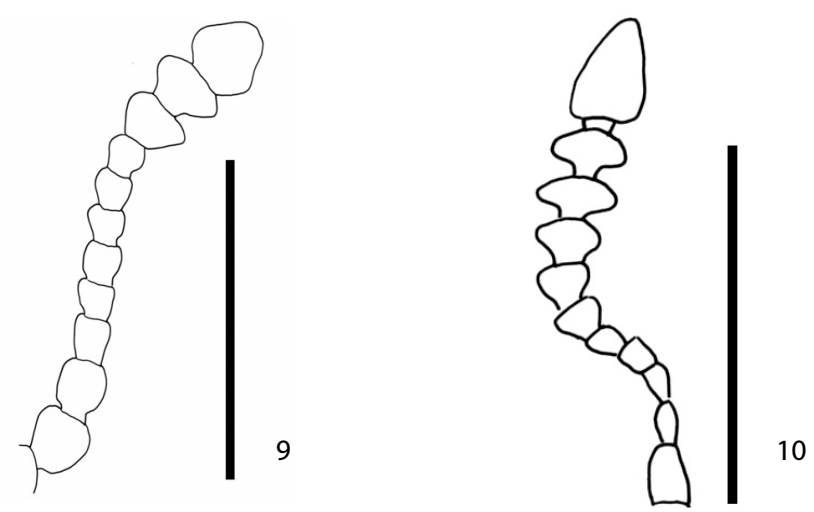

Figs. 9-10. Antenna of Holostrophus (scale bar $=1 \mathrm{~mm}$ ): 9. Pisenus insignis, 10. Holostrophus (Paraholostrophus) orientalis.

successional stages II-III of host fungi, therefore its host fungi is more harder before the fruiting bodies were decayed entirely.

\section{Holostrophus diversefasciatus Pic 두줄무늬애 버섯벌례붙이 (신칭)}

(Figs. 3, 8)

\begin{abstract}
Holostrophus diversefasciatus Pic, 1921: 1.
\end{abstract} Holostrophus katoi Nomura, 1959: 42.

Description. Body length 4.5-5.0 mm. Body elliptical, elongate-oval, convex, weakly glossy; with dense punctures with decumbent and yellowish brown pubescence; elytra with two fascia bands; head black; antennae, antero-lateral margins of pronotum, ventral side of body and legs yellowish brown; elytra black with two yellowish brown fascia band. Head downward, weakly visible dorsally; eyes emarginate, reaching antennal fossae; antennae relatively short, not reaching to basal part of pronotum, widening from antennomere 7 to apex; apical antennomere long triangular, fourth maxillary palpomere subsecuriform. Pronotum triangular; with distinct lateral carinae; all lateral margins slightly marginate, not visible dorsally, lateral sides abruptly narrowed anteriad; basal margin sinuous, with short longitudinal sulcus on subbasal part. Elytra convex, distinctly tapered apically; not striate; black, with two yellowish brown fascia bands; anterior fascia bands near humeral; posterior fascia bands at subapical part. All legs slender; all tibiae with two spurs at apex; tarsomere 1 longer than tarsomeres 2 and 3 combined together.

Specimens examined. <GS>: 1 ㅇ. Okhyeon-ri, Jije-myeon, Yangpyeong-gun, 14 V 2007, B.-H. Jung ex Coriolus versicolor
(L.: Fr.) Quél.

Distribution. Korea (Central - New record), Russia (Far East), Japan, China (Northeast Territory).

\section{Acknowledgements}

"The Survey of Korean Indigenous Species" supported by National Institute of Biological Resources (NIBR) of Ministry of Environment of Korea. And also I would like to express my sincere gratitude to Dr. Hae Chul Park of the National Institute of Agricultural Science and Technology for critical comments on manuscript and Dr. Nicholai B. Nikitsky for providing the valuable papers and materials.

\section{Literature Cited}

Billberg, G.J. 1820. Enumeratio Insectorum in Museo Gust. Joh. Billberg. Gadelianis, 138 pp.

Casey, T.L. 1900. Review of the American Corylophidae, Cryptophagidae, Tritomidae, and Dermestidae, with other studies. J. New York Entomol. Soc. 8: 51-172.

Crowson, R.A. 1955. The Natural Classification of the Families of Coeoptera. N. Lloyd. London. pp. 1-187.

Crowson R.A. 1964. Observations on British Tetratomidae (Col.), with a key to the larvae. Entomol. Month. Mag. 99: 82-86.

Graves, R.C. 1960. Ecological observations on the insects and other inhabitants of woody shelf fungi (Basidiomycetes: Polyporaceae) in the Chicago area. Ann. Entomol. Soc. America. 53: 61-78.

Gistel, J. 1856. Die Mysterien der europäischen Insectenwilt. 530 pp. T. Dannheimer, Kempten.

Horn, G.H. 1888. Miscellaneous Coleopterous studies. Trans. American Entomol. Soc. 15: 26-48. 
Hayashi, N. 1975. On the larvae of Melandryidae (Col., Cucujoidea) and some related families occurring in Japan. Kontyu, Entomol. Soc. Japan 43(2): 147-169.

Kim, J.I. 2002. A tentative list of Korean Coleoptera (Insecta) containing a species of newly recorded family, J. Korean Biota 7: 225-261.

Kim, J.I. and S.Y. Kim. 1996. Coleoptera fauna of the Mt. Pangtae, Inje-Kun, Kangwon-do, Korea. Rep. Kor. Conserv. Nat.. 37: 121-131.

Kirby, W. 1837. The Insects. In: Fauna Boreali-Americana, or the Zoology of the Northern Parts of British America (Part 4), eds by J. Richardson. 325 pp. Josiah Fletcher, Norwich.

Klimaszewski, J. and S.B. Peck. 1987 Succession and phenology of beetles faunas (Col.) in the fungus Polyporellus squamoxs (Huds.: Fr.) Karst. (Polyporaceae) in Silesia, Poland. Canadian J. Zool. 65: $542-550$

Lawrence, J.R. 1982. Coleoptera. Pp. 482-553. In: Synopsis and classification of living organisms, ed. by S. P. Parker, Volume 2. McGraw-Hill. NY.

Lawrence, J.F. and A.F. Newton. 1982. Evolution and classification of beetles. Ann. Rev. Ecol. and Syst. 13: 261-290.

Lawrence, J.F. and A.F. Newton. 1995. Families and subfamilies of Coleoptera (with selected genera, notes, references and data on family-group names), pp. 779-1006. In: J. Biology, phylogeny, and classification of Coleoptera, eds by Pakaluk and S.A. Slipinski. Papers celebrating the 80th birthday of Roy. A. Crowson. Muzeum I Instytut Zoologii PAN, Warszawa. pp. 1-1,092.

Leschen, R.A.B. 1990. Tenebrionoid-Basidiomycete relationships with comments on feeding ecology and the evolution of fungal mycophagy (Col. Hymenomycetes). University Kansas Sci. Bul. 54: $165-177$

Lewis, G. 1895. On the Cistelidae and other heteromerous species of Japan. Ann. and Mag. Nat. Hist. Ser. 6. 15(87): 250-279.

Minch, F.L. 1952. Insect inhabitants of Polyporus betulinus. J. New York Entomol. Soc. 60:31-35.
Miyatake, M. 1960. The genus Pisenus Casey and some notes on the family Tetratomidae (Coleoptera). Trans. Shikoku Entomol. Soc. 6: 121-134.

Nikitsky, N.B. 1989. The beetle families Tetratomidae and Melandryidae of the USSR Far East. In: Ecosystematics of insects of Siberia and the Far East. Studies on the fauna of the Soviet Union, eds by A. I. Shatalkin. Archi. Zool. Mus. Moscow State Uni. 27: 3- 87.

Nikitsky, N.B. 1992. News on the genus Triphylia Reitter, 1898 (Coleoptera, Tetratomidae). Elytron 5 (1991): 159-168.

Nikitsky, N.B. 1998. Generic classification of the beetle family Tetratomidae (Coleoptera, Tenebrionoidea) of the world, with description of new taxa. Pensoft, Sofia. 80 pp.

Nomura, S. 1959. Notes on the Japanese Melandryidae (Coleoptera). I. Entomol. Rev. Japan 10: 43-45.

Park, O., J.A. Lockettm and D.J. Myers. 1931. Studies in noctural ecology with special reference to climax forest. Ecology 12: 709-727.

Pic, M. 1921. Notes diverses, descriptions et diagnoses (Suite). L' Échange, Revue Linnéenne 37: 1-6.

Reitter, E. 1889. Zwei neue Coleopteren-Gattungen aus Transkaukasien. Wiener Entomologische Zeitung 8: 245

Say, T. 1824. Apppendix. Part I. - Natural History. I. Zoology: E. Class Insecta. Coleroptera. pp. 268-348. In: Narrative of an expedition to the source of St. Peter's River, lake Winnepeek, lake of the Woods, etc. etc. performed in the year 1823, by the order of the Hon J.C. Calhoun, secretary of the war, under the command of Stephen H. Long, Major U.S.T.E compiled from the notes of major Long, Messrs. Say, Keating, and Calhon, Vol. 2, by William H. Keating. A.M. etc. Philadelphia.

Young, D.K. and D.A. Pollock. 2002. Tetratomidae Billberg 1820. pp. 413-416. In: American Beetles, Volume 2: Polyphaga: Scarabaeoidea through Curculionoidea, eds. by R.H. Arnett, Jr., M.C. Thomas, P.E. Skelley, and J.H. Frank. CRC Press, Boca Raton, Florida, USA 